\title{
Customer Retention Strategies Effectiveness in the Zimbabwean Medical Industry: Perspectives from Cellmed Health Fund
}

\author{
${ }^{1}$ Vingirayi Ishumael, ${ }^{2}$ Nyagadza Brighton, ${ }^{3}$ Mavhunga Charles, and ${ }^{4}$ Nyasha Munjeri
}

\begin{abstract}
The main objective of the study was to examine customer retention strategies at Cellmed Health, from the period 2012 to 2018. The focused was mainly on impact of customer retention strategies on market share, profit and sales turnover. A descriptive survey design was used with both qualitative and quantitative methods. Sixty participants from Cellmed Health were involved in the research. The study used both primary and secondary data where the primary data was collected using questionnaires and interviews while the secondary data was obtained from annual reports and magazines of the company. Descriptive statistics of mean, frequency and percentages were used to analyse demographic characteristics of the respondents. Regression analysis was used to measure and predict the relationship between the customer retention strategies and market share, profitability and sales turnover. Findings were that Cellmed used monitoring customer relationships strategies, market intelligence, loyalty programs and promotions to maintain its competitiveness. Furthermore, it also concludes that there was a significant relationship between customer retention strategies and profit as well as sales turnover that the company (Cellmed) was posting annually. In this light, the study recommendation was that customer retention strategies should be embrace in the decision making processes of the organisation covering products, price, services, responsiveness, tangibility and reliability of the brand name. The study also recommends that Cellmed Health should strengthen its customer bonds and moreover, in order to increase customer retention rates, Cellmed Health should provide extraordinary customer services.
\end{abstract}

Key Words - Customer Retention, Competition, Strategy, Market Intelligence

\section{INTRODUCTION}

Retaining customers is important for growth and success of any business organization irrespective to tangible goods industry or intangible (service industry). Customer retention is defined by [19] as the marketing goal of preventing

Published on December 5, 2019.

${ }^{1}$ Programme Co-ordinator (Marketing Management), Zimbabwe Open University (ZOU), Business Management Department, Faculty of Commerce, Harare/Chitungwiza Regional Campus, Harare. Zimbabwe. Email Address: ivingirayi2009@gmail.com

${ }^{2}$ Digital Marketing Lecturer, Marketing Management Department, Marondera University Agricultural Sciences \& Technology (MUAST), Faculty of Agribusiness \& Entrepreneurship, Marketing Management Department, Marondera, Zimbabwe. ORCID: https://orcid.org/0000-00017226-0635. Email Address: brightonnyagadza@gmail.com

${ }^{3}$ Zimbabwe Open University (ZOU), Marketing Management Department, Faculty of Commerce, Harare/Chitungwiza Regional Campus, Harare. Zimbabwe. Email: mavhungac@gmail.com

${ }^{4}$ Zimbabwe Open University (ZOU), Marketing Management Department, Faculty of Commerce, Harare/Chitungwiza Regional Campus, Harare. Zimbabwe. customers from going to the competitor. [12] defines customer retention as the way in which organizations focus their efforts on existing customers in an effort to continue doing business them. [24] further defines customer retention as a process through in which a business ensures customers enter the sales funnel and become repeat customers. Research has shown that it is five times cheaper to retain a customer than to acquire a new customer. Thus it becomes important for all business organizations to strive for retaining their customers. Over the past decades, practitioners and academics have paid considerable attention to customer retention and its antecedents and consequences, primarily because of the impact of retention on customer life time value and consequently on the firm's bottom line [4]. Gaining sustainable competitive advantage over competitors through satisfying customer relationships has become one of the strategic weapons for a modern day service firm [26]. The quality of relationship with their customers has been established [24] which stimulates customer satisfaction and loyalty [13].

[15] noted that competitors are always on the look out to steal customers through better deals. The consequences of customer retention also compound over time, and in sometimes unexpected ways, even a tiny change in customer retention can cascade through a business system and multiply over time. The fact that customer profitability tends to increase over the life of a retained customer is added incentive for businesses to allocate more resources to sharpening their customer retention strategies.

\section{RESEARCH CONTEXT \& PROBLEM STATEMENT}

The Zimbabwe Medical Aid funders' field has over the last decade witnessed the entry of a significant number of players which has seen intense competition dominating the medical fund industry. To date, there are twenty-seven medical aid funders in Zimbabwe who are registered with the Association of Healthcare Funders Zimbabwe [1]. Most product and service developments in the medical industry are easy to duplicate and when medical aid players provide nearly identical services, they can only distinguish themselves on the basis of price and quality. Therefore, customer retention is potentially an effective tool that medical aid funders can use to gain a strategic advantage and survive in today's ever-increasing competitive environment. Cellmed Health Medical Fund is a subsidiary of Cell Holdings. It is one of the few companies that offer self-funded medical aid solutions, a medical aid which is administered through a fund set aside by the company on 
behalf of its employees and elected beneficiaries or any organized grouping, is one of the fastest growing medical aid funds in Zimbabwe. CellMed was licensed to operate as a medical aid fund in 2009 and since 2010 the Fund has been offering uncomplicated and hassle free medical solutions at competitive prices. The Fund's customer base cuts across various sectors of the economy which include mining, energy, manufacturing, financial, educational, civil society and small to medium enterprises. The Mission of Cellmed Health Medical Fund is to be the industry leader in the provision of health services through Alternative Risk Transfer Solutions and its vision is to unlock stakeholder value through innovative health solutions. The significance of retaining customers is not new in the business context. [6] posits that marketing is as much concerned with acquiring as well as retaining customers. In recent times, there has been a tremendous proliferation of medical aid fund companies into the Zimbabwe economy attributed to by the decay of services in public hospitals which have resulted in citizens seeking private hospitals attention in the direction of obtaining better and satisfactory services. The influx of these medical aid fund companies coupled with their enhanced customer service practices has led to fierce competition in the industry. With customers having an option of hopping from one fund to another at any given time looking for "value for money" customer retention has become a substance of immense concern in the industry. [10] in their study noted that businesses in the medical industry generally suffers losses of between 15 to 20 percent of their customer base each year. On the other hand, while medical schemes are experiencing significant reductions in membership, Cellmed Health has not been spared. As competition for market share by many players in the medical industry has become tense, Cellmed Health Company has witnessed a significant fall in the membership with high indications that the reduction has been mainly attributed to customer retention strategies employed by the organization. Evolving from this backdrop, this study, therefore, seeks to investigate and assess on the customer retention strategies employed by Cellmed health.

\section{BRIEF LITERATURE REVIEW}

\section{Defining Customer retention}

Customer retention is defined by [5] as the number of customers doing business with a firm at the end of a financial year expressed as a percentage of customers that were active at the beginning of the year. From this definition we deduce that customer retention involves maintaining long-term relationships in a quest to generate a repurchase behaviour. [2] defines customer service as an assessment of the product or service quality provided by a business that measure how loyal its customers are. Customer retention is also the process when customers continue to buy products and services within a determine time period [14]. Customer retention is the way in which organizations focus their efforts on existing customers in an effort to continue doing business with them [12]. However, customer retention can also mean the number of customers who stay with the provider in the course of an established period, such as a year [8]. According to [11] customer retention may be viewed from both an attitudinal and a behavioural perspective and there is need to look at both the behavioural and attitudinal consequences of any intervention of the marketing effort.

\section{Customer retention strategy}

A customer retention strategy is a process through which a business ensures customers enter the sales funnel and become repeat customers [24]. Customer retention strategies were also defined [7] as all the strategies that focuses on a firm's existing customers with the aim of securing a customer's loyalty over a period of time. Customer retention and customer service are important because they result in increased product quality, improved competitive advantage, improved profitable opportunities and as a result increased sales and income. In the domain of customer services, vast activities can be explored. On the other hand, customer retention strategies include service quality, service recovery, customer satisfaction, product mix strategy and perceived price fairness.

Monitoring and evaluating relationships is one of the basic strategies employed by firms to retain customers over time [14]. [26] postulated that firms can employ monitoring customer relationships through two ways which are the use of relationship surveys and customer databases. There is need to survey on current customers of a firm and this helps to establish their perceptions on the received quality, value, satisfaction with services, and satisfaction with the service provider as opposed to competitors.

\section{Loyalty Programs}

Loyalty programs are aimed at increasing customer retention in profitable segments by providing increased value and satisfaction to customers [18] argue that the main aim of loyalty programs is to reward customers for repeated purchases thereby building customer retention. [17] further cited that increased satisfaction and loyalty leads to increased profitability. Managers usually believe that it is desirable and expected for the loyalty reward program to be properly executed in order to increase customer retention rate [13].

\section{Customer Clubs}

Organizations can establish customer clubs which are meant to deliver a range of benefits to their members. Here the organization create more or less formalized gatherings of its customers where the common basis for membership is that the individual is a current or has been a customer to the company [14]. [23] posits that the effects of customer retention through customer clubs comes through customer interaction, customer knowledge and customer benefit. Customer interaction, which is done by creating contact and feedback opportunities refers to the frequency of the interactions between the firm and its customers. [23] further argues that close contact around the client throughout the customer relationship life cycle is crucial in increasing the customer retention rate.

\section{Marketing Intelligence}

Through market intelligence it becomes easy for one to get early warning of competitor moves and therefore enables 
counter measures and minimizes investment risks by early detection of threats and trends. Better customer interaction, intensified customer market view, better market selection and positioning enables the company to understand where the product and service offer fits and allows the discovering of untapped or under-served potential market, more efficient and cost-effective information [7]. Website traffic analysis also helps to understand what customers are looking for and may also include a high degree of valuable information about who is looking for your products and services.

\section{CONCEPTUAL FRAMEWORK}

Based on the discussed background of the study, problem of the statement and literature review the study adopted the conceptual framework below.

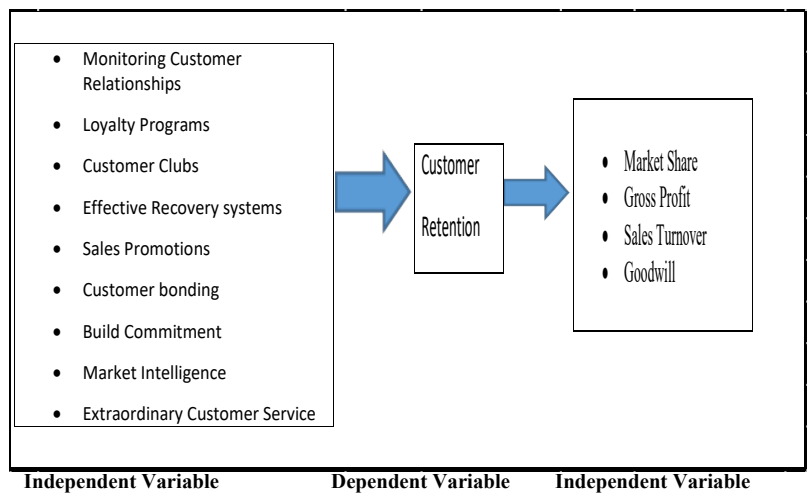

Fig 1: Conceptual Framework on customer retention. Source: Authors (2019).

\section{RESEARCH METHODOLOGY}

This research study was conducted through a descriptive case study research design. This research adopted a case study design. A case study explains relationships that exist in reality. The study opted for case study design because it allows the researcher to capture reality in greater detail. A case study allows the study of a phenomenon in its natural setting and also allows for data collection from one or a few entities (people, groups or organizations). A case study also is suitable when the focus is on a recent event. To yield the maximum benefits of both approaches, the researchers used both qualitative and quantitative research approaches. Data collection tools are the instruments which are used to collect the necessary information needed to serve or prove some facts [12]. Primary and secondary data sources were used in this study. The population frames were taken from organizational database of employees and the register of directors as follows:

Table 3.4.1: Sample Frame

\begin{tabular}{|l|l|}
\hline Respondent Class & Population \\
\hline Board of Directors & 8 \\
\hline Senior Managers & 12 \\
\hline Middle Managers & 15 \\
\hline Junior staff & 25 \\
\hline Total & $\mathbf{6 0}$ \\
\hline
\end{tabular}

Total population: $=60$
To determine the size of the sample used, the Yamani Taro formula was used. It states that the desired sample size is a function of the target population and the maximum acceptable margin of error (also known as the sampling error) and is expressed mathematically thus:

Where:

$$
\mathrm{n}=\frac{N}{1+N e^{2}}
$$

$$
\begin{aligned}
& \mathrm{n}=\text { sample size } \\
& \mathrm{N}=\text { target population }(60) \\
& \mathrm{e}=\text { maximum acceptable margin of error }(5 \%)
\end{aligned}
$$

\section{Sample size calculation}

$$
\begin{aligned}
& \mathrm{n}=\frac{60}{1+60(0.05)^{2}} \\
& \mathrm{n}=52
\end{aligned}
$$

Sample size calculation produced 52 respondents. The sample size consisted of employees from different functional areas of the business who work at the Cellmed Health in Harare. The survey could not be extended to staff from other branches in Bulawayo, Mutare, Zvishavane and Hwange due to time constraints. The study population was mainly Cellmed Health staff with however targeted key respondents that included the marketing, sales, claims, underwriting, finance and human resources personnel taking into account all levels from low management staff, middle management, senior management and executive management such as marketing directors or operations directors due to the role they play in strategy decision making. Purposive sampling technique was used to select the respondents. According to this method, sample members are selected on the basis of their knowledge, relationships and expertise regarding a research subject. A well-structured questionnaire and document analysis were considered as the most appropriate research instruments for the study. In this study, the researcher distributed total of 60 questionnaires to various directors, senior managers, middle managers and junior staff members in different departments and provinces. A follow up was done using telephone calls and emails. The researchers used structured interviews with a set of closed predetermined questions. The collected data was first edited, coded and entered in Statistical Package for Social Sciences (SPSS) version 20.0 for analysis which offered extensive data handling capabilities and numerous statistical analysis procedures that analysed small to very large data statistics. The Regression model adopted for the study to determine the impact of customer retention on market share, turnover and profit is as follows:

$$
\begin{aligned}
& Y=A+\beta 1 X 1+\beta 2 X 2+\beta 3 X 3+e \\
& \text { Where: } X 1=\text { Monitoring Customer Relationships, } \\
& X 2=\text { Loyalty Programs, } \\
& X 3=\text { Customer Clubs, } \\
& X 4=\text { Effective Recovery Systems, } \\
& X 5=\text { Sales Promotions, } \\
& X 6=\text { Creating bonds binding the customer to the firm, } \\
& X 7=\text { Building Commitment, } \\
& X 8=\text { Market Intelligence, } \\
& X 9=\text { Extraordinary Customer Service. } \\
& \beta=\text { Beta Coefficient. }
\end{aligned}
$$


$A=$ Constant and

$Y=$ (Market share, Turnover and Profitability)

\section{RESEARCH RESULTS}

\section{Demographic Data}

Table 1: Questionnaire response rate

\begin{tabular}{|l|c|c|c|c|}
\hline Instrument & Frequency & $\begin{array}{l}\text { Success } \\
\text { Rate }\end{array}$ & $\begin{array}{l}\text { Negative } \\
\text { rate }\end{array}$ & Total \\
\hline Questionnaires & 100 & $85 \%$ & $15 \%$ & $100 \%$ \\
\hline Interviews & 30 & $90 \%$ & $10 \%$ & $100 \%$ \\
\hline & & & & \\
\hline
\end{tabular}

\section{Source: Authors' Field work (2018)}

Table 1 shows that the success rate for questionnaires was $85 \%$ and $15 \%$ of the respondents failed to participate. On Interviews, the success rate was $90 \%$ and only $10 \%$ of the interviews set were unsuccessful. This result shows that the research was successful because the majority of respondents participated in both interviews and questionnaires. [2] pointed out that a response rate of $50 \%$ is adequate to conduct an analysis, while $60 \%$ and $70 \%$ are considered as good and very good respectively.

\section{Gender of respondents}

To avoid gender bias towards the study subject, a consideration was made on the respondents' gender to incorporate the views of both male and female participants. A presentation of the respondents' gender distribution is shown below on Fig 1 (below):

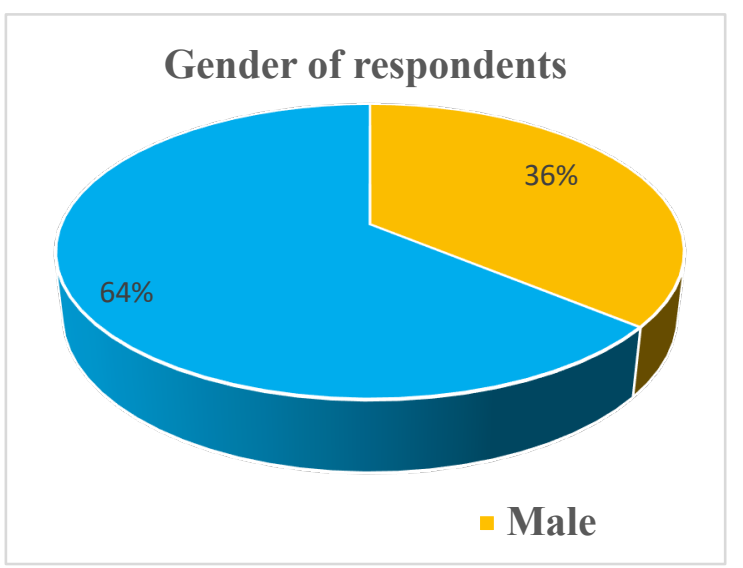

\section{Figure 1: Gender of Respondents}

Source: Authors' Field work (2018)

A greater proportion of the respondents (64\%) were female while male respondents consisted of $36 \%$ of the sample. According to [21] it is natural phenomenon that males and females have different attitudes toward work place situations and events. Females hold different views and from the study it is evident that there was a gender imbalance with females dominating the sample.

\section{Age of Respondents}

With regards to age groups, all the respondents stated their age group. Figure 4.2 that follows shows the age distribution of the respondents.
Figure 4.2: Age of respondents

\begin{tabular}{|c|c|c|}
\hline Age & Percentage $\%$ & $\begin{array}{c}\text { Cumulative } \\
\text { Frequency }\end{array}$ \\
\hline Below 29 & $2 \%$ & $2 \%$ \\
\hline $\mathbf{3 0 - 3 9}$ & $29 \%$ & $31 \%$ \\
\hline $\mathbf{4 0 - 4 9}$ & $42 \%$ & $73 \%$ \\
\hline $\mathbf{5 0 - 5 9}$ & $21 \%$ & $94 \%$ \\
\hline $\mathbf{6 0} \&$ above & $6 \%$ & $100 \%$ \\
\hline Total & $\mathbf{1 0 0} \%$ & $\mathbf{1 0 0} \%$ \\
\hline
\end{tabular}

Source: Authors' Field work (2018)

The study findings show that the majority $(42 \%)$ of the respondents were between the age group of 40 to 49 years, followed by 30 to 39 years (29\%), and 50-59 years with (21\%). The lowest was $2 \%$ in the age group of 20 to 29 years. The results signify that all age groups were represented in the study and it was concluded that the respondents were mature enough to handle and respond to the issue of customer retention and the subject matter under review.

\section{Level of Education of Respondents}

General information of respondents also included their highest level of education. Figure 4.3 below is a presentation of the findings on respondents' education.

Figure 3: Level of education of respondents

\begin{tabular}{|l|c|c|}
\hline Description & $\begin{array}{l}\text { Percentage } \\
\%\end{array}$ & $\begin{array}{c}\text { Cumulative } \\
\text { Frequency }\end{array}$ \\
\hline $\begin{array}{l}\text { Secondary } \\
\text { (Ordinary } \\
\text { Advanced Level) }\end{array}$ & $15 \%$ & $15 \%$ \\
\hline Certificate/Diploma & $35 \%$ & $50 \%$ \\
\hline Degree & $40 \%$ & $90 \%$ \\
\hline Postgraduate & $10 \%$ & $100 \%$ \\
\hline Total & $\mathbf{1 0 0} \%$ & $\mathbf{1 0 0 \%}$ \\
\hline
\end{tabular}

Source: Authors' Field work (2018)

The majority of the respondents were graduates, holding undergraduate degrees as their highest academic qualification. Diplomas and Master's degree qualified constituted $35 \%$ and $10 \%$ respectively while Ordinary Level and Advanced Level holders constituted 15\%. From this observation, it was concluded that all the respondents had sound basic education with a greater proportion having attained tertiary education and thus were sufficiently qualified to interpret and address the research questions.

\section{Department Enrolled}

Respondents were asked to indicate their respective departments at the time of the study as it may have a bearing on their perception of the firm's customer retention strategies. Individuals who are privy to the designing of customer retention strategies may find it difficult to criticize 
their own work, hence the need to incorporate employees from all levels to obtain a balanced view. Figure 4 below is a presentation of the findings that were obtained.

Table 2: Respondents Departments Enrolled at Cellmed Health

\begin{tabular}{|l|l|c|c|c|c|}
\hline \multicolumn{2}{|l|}{} & $\begin{array}{l}\text { Frequenc } \\
\text { y }\end{array}$ & \multicolumn{1}{l|}{$\%$} & Valid \% & $\begin{array}{l}\text { Cumulativ } \\
\text { e } \%\end{array}$ \\
\hline \multicolumn{1}{|l|}{ Marketing } & 16 & 27 & 27 & 27 \\
\cline { 2 - 6 } & 8 & 13 & 13 & 40 \\
\hline $\begin{array}{l}\text { Humance } \\
\text { Resources }\end{array}$ & 4 & 7 & 7 & 47 \\
\cline { 2 - 6 } Operations & 26 & 43 & 43 & 90 \\
\hline Others & 6 & 10 & 10 & 100 \\
\hline Total & 60 & 100 & 100 & 100 \\
\hline
\end{tabular}

Source: Authors' Field work (2018)

\section{Customer Retention Strategies at Cellmed Health}

This section describes in detail the extent of the adoption of customer retention strategies at Cellmed Health and impact of those customer retention strategies on market share, profitability and sales turnover.

\section{Table 3: Customer retention strategies adopted at Cellmed Health}

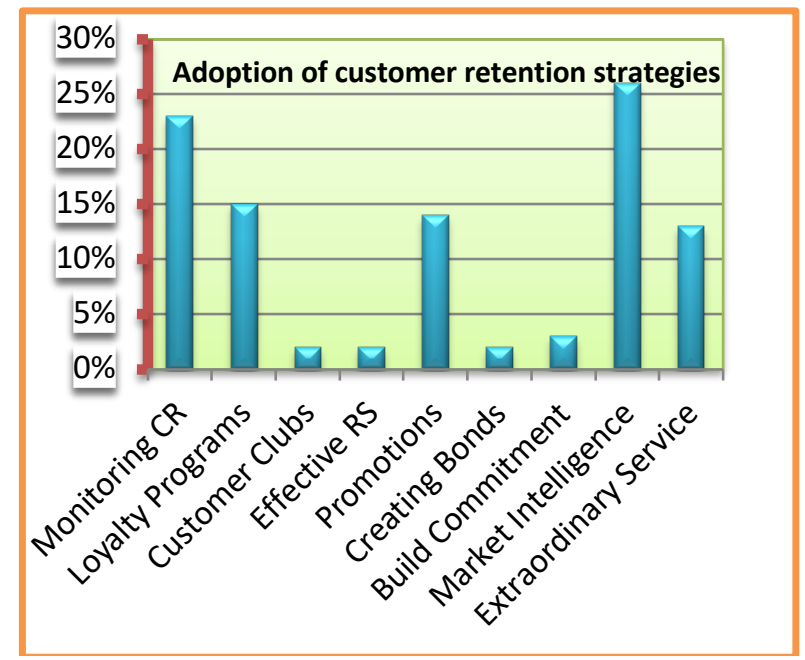

Source: Authors' Field work (2018)

\section{Market Intelligence}

The findings indicate that Market Intelligence is the most adopted customer retention strategy at Cellmed Health, with a percentage of $26 \%$. This also implies that Cellmed Health focuses more on acquiring and analysing information on markets and customer orientation, determining the future needs of existing and future customers, identifying new trends in markets and competitors and investing in content marketing. This implies that this strategy has been adopted to a very large extent.

\section{Monitoring Customer Relationships}

The findings, as shown in Table 4.3 highlights that monitoring customer relationships has been adopted to a large extent with $23 \%$ of the population agreeing to the adoption of the strategy. Cellmed maintains databases that keep track of customer's purchases, preferences, complements and complaints and keeps constant communication on the latest updates to members through messages and emails The organisation also adopts the use of relationship surveys and through its website undertakes analysis to understand what customers are looking for and why. The company also widely sources and analyses information from the competitive environment (competitive intelligence).

\section{Loyalty Programs}

The findings also show that loyalty programs have been adopted to a large extent at Cellmed Health, with study results showing a $15 \%$ result. Loyalty programs adopted at Cellmed health include building customer loyalty programs of awarding most loyal clients, hospital visits to admitted members and follow ups even when they are discharged. The company also sends birthday messages to members and for the big corporates including sending a birthday cake for the executives and rewarding longest members since fund inception; for both corporates and individuals with memorable gifts.

\section{Promotions}

Promotions are also used at Cellmed Health, on a moderate scale with $13 \%$ result. The reason why promotions have not been largely adopted is because they swallow from company resources and thus need more resources to be funded. Discounts for long membership, rebates and refunds for customers for continuous membership are the promotional activities undertaken by Cellmed. The company also rewards members for good claims performance and gives out corporate branded wear to its customers such as caps, hats, T-shirts and shirts, umbrellas and hampers. It also gives out small giveaways that are usually handed out to walk in members at our reception e.g. ball point pens and key rings etc.

\section{Creating bonds}

This strategy has been adopted to a lesser extent (2\%) result. This implies that this strategy may have little returns to the organisation resulting in less adoption.

\section{Customer clubs}

Customer clubs have also been adopted to a less extent at Cellmed Health (2\%) result. These clubs include activities such as Having luncheons or cocktails with the clients and holding events like wellness days, fun runs for club members.

\section{Effective recovery systems and build commitment}

These strategies have also been adopted to a less extent at Cellmed Health (2\%) and (3\%) respectively. Cellmed health has done little in terms of expanding distribution channels as a way of increasing our accessibility to our members, increasing visibility and improving our service delivery.

\section{Extraordinary Customer Service}

This strategy has been adopted to a large extent at Cellmed Health (13\%). This entails that Cellmed Health tries to offer services that goes above and beyond the call of duty and providing quality in all its activities. The results also 
indicate that customer retention strategies have generally been adopted to a moderate extent at Cellmed Health. The findings are consistent with a study by [16] who posited that very few organizations have measured to the economic values of their customer retention strategies. Kotler (2003) also observed that in recent times more companies are recognizing the importance of satisfying and retaining customers because they constitute the relationship capital [24]. [15] also observed that insurance companies are now recognizing the need for customer retention.

\section{Impact and effectiveness of the customer retention strategies at Cellmed Health}

The study also sought to understand the extent to which the customer retention strategies used by Cellmed Health contribute to the performance of the company terms of revenue/turnover, market share and profit. The results are presented below.

\section{Impact of Customer Retention Strategies at Cellmed Health on Market Share}

Presented in Table 4 are the results from responses obtained when respondents were asked to rate on a fivepoint Likert scale the extent to which customer retention strategies impact on market share.

\section{Table 4: Impact of Customer Retention Strategies on}

\section{Market Share}

\begin{tabular}{|c|c|c|c|c|c|c|}
\hline $\begin{array}{l}\text { Independen } \\
\text { t Variables }\end{array}$ & Coef. & oIM & $\mathbf{Z}$ & $>|\mathbf{z}|{ }^{P}$ & $\begin{array}{l}{[95 \%} \\
\text { Conf. }\end{array}$ & $\begin{array}{l}\text { Interval } \\
\text { ] }\end{array}$ \\
\hline a.Constant & 1.55 & Err ${ }_{\text {Etd. }}$ & & & & \\
\hline $\begin{array}{l}\text { customer } \\
\text { relationships }\end{array}$ & $\begin{array}{c}0.29 \\
8593\end{array}$ & $\begin{array}{c}0.05 \\
2297\end{array}$ & $.71^{5}$ & 0 & $\begin{array}{l}0.196093 \\
2\end{array}$ & $\begin{array}{c}0.40 \\
1093\end{array}$ \\
\hline $\begin{array}{l}\text { Loyalty } \\
\text { programs }\end{array}$ & $\begin{array}{c}- \\
.079581\end{array}$ & $\begin{array}{l}0.04 \\
7713\end{array}$ & $.67^{3}$ & $.012^{0}$ & $\begin{array}{l}- \\
0.013935 \\
2\end{array}$ & $\begin{array}{l}0.17 \\
3095\end{array}$ \\
\hline $\begin{array}{l}\text { Customer } \\
\text { clubs }\end{array}$ & $\begin{array}{l}0.09 \\
7792\end{array}$ & $\begin{array}{l}0.05 \\
3561\end{array}$ & $.01^{1}$ & $.068^{0}$ & $\begin{array}{l}- \\
0.202767 \\
3\end{array}$ & $\begin{array}{l}0.27184 \\
7\end{array}$ \\
\hline Effective RS & $\begin{array}{c}0.07 \\
9322\end{array}$ & $\begin{array}{l}0.07 \\
0196\end{array}$ & $.22^{3}$ & $.134^{0}$ & $\begin{array}{l}{ }^{-}- \\
0.052259 \\
1\end{array}$ & $\begin{array}{l}0.22 \\
2902\end{array}$ \\
\hline Promotions & $\begin{array}{c}0.23 \\
5632\end{array}$ & $\begin{array}{l}0.02 \\
3650\end{array}$ & $.23^{4}$ & ${ }^{0}$ & $\begin{array}{l}- \\
0.025356 \\
1\end{array}$ & $\begin{array}{c}0.23 \\
2635\end{array}$ \\
\hline $\begin{array}{l}\text { customer } \\
\text { bonds }\end{array}$ & $\begin{array}{c}0.11 \\
2259\end{array}$ & $\begin{array}{c}0.05 \\
1516\end{array}$ & $.18^{2}$ & $\begin{array}{l}0 \\
.029^{0}\end{array}$ & $\begin{array}{l}0.011289 \\
5\end{array}$ & $\begin{array}{l}0.21 \\
3228\end{array}$ \\
\hline $\begin{array}{l}\text { Build } \\
\text { commitment }\end{array}$ & $\begin{array}{l}0.11 \\
2259\end{array}$ & $\begin{array}{r}0.14 \\
7664\end{array}$ & $.52^{1}$ & $.129^{0}$ & \begin{tabular}{l}
\multicolumn{1}{c}{-} \\
0.064965 \\
1
\end{tabular} & $\begin{array}{l}0.51 \\
3866\end{array}$ \\
\hline $\begin{array}{l}\text { Market } \\
\text { intelligence }\end{array}$ & $\begin{array}{c}0.38 \\
1246\end{array}$ & $\begin{array}{c}0.06 \\
4104\end{array}$ & $.95^{5}$ & $\begin{array}{c}0 \\
.000\end{array}$ & $\begin{array}{l}0.255605 \\
1\end{array}$ & $\begin{array}{l}0.50 \\
6894\end{array}$ \\
\hline $\begin{array}{l}\text { Extraordinar } \\
\text { y CS }\end{array}$ & $\begin{array}{l}0.23 \\
2361\end{array}$ & $\begin{array}{l}0.33 \\
5681\end{array}$ & & $.023^{0}$ & \begin{tabular}{l}
\multicolumn{1}{c}{-} \\
0.202767 \\
3
\end{tabular} & $\begin{array}{l}0.27 \\
1847\end{array}$ \\
\hline \multicolumn{7}{|l|}{ Fit Indices } \\
\hline chi-square & 0 & & & & & \\
\hline $\begin{array}{l}\text { Degrees of } \\
\text { freedom }\end{array}$ & 0 & & & & & \\
\hline p-value & 0 & & & & & \\
\hline RMSEA & 0 & & & & & \\
\hline CFI & 1 & & & & & \\
\hline SRMR & 0 & & & & & \\
\hline TLI & 1 & & & & & \\
\hline b. Dep & ariat & Share & & & & \\
\hline
\end{tabular}

\section{Source: Authors' Field work (2018)}

a. Predictors: (Constant), Extraordinary customer service, Sales promotion, Build commitment,

M customer relationships, Customer clubs, Loyalty programs, Effective recovery system,

Market intelligence (sales volume), Creating customer bonds

b. Dependent Variable: Market Share

From the regression findings, the substitution of the equation $(\mathrm{Y}=\mathrm{A}+\beta 1 \mathrm{X} 1+\beta 2 \mathrm{X} 2+\beta 3 \mathrm{X} 3+\beta 4 \mathrm{X} 4+\mathrm{e})$ becomes:

$\mathrm{Y}=+1.55+0.29859 \mathrm{X} 1+\quad 0.079581 \mathrm{X} 2+\quad 0.097792 \mathrm{X} 3+$ $0.079322 \mathrm{X} 4+\quad 0.235632 \times 5+0.112259 \times 6+\quad 0.224451 \times 7+$ $0.381246 \mathrm{X} 8+0.232361 \times 9$.

Where: $\mathrm{Y}$ is the dependent variable (Market Share), $\mathrm{X} 1$ is Monitoring customer relationships, X2 is Loyalty Programs, $\mathrm{X} 3$ is Customer Clubs, X4 is Effective Recovery Systems, $\mathrm{X} 5$ is Promotions, $\mathrm{X} 6$ is Creating customer bonds, $\mathrm{X} 7$ is Build Commitment, $\mathrm{X} 8$ is Market Intelligence and $\mathrm{X} 9$ is Extraordinary customer service.

The results of the correlation matrix shown in Table 4 above, indicates that customer retention strategies have a positive correlation with market share. This indicates that an increase in increase in monitoring customer relationships will lead to a 0.298 increase in market share; a unit increase in loyalty programs will lead to a -0.079581 increase in market share; a unit increase in customer clubs will lead to a 0.097792 increase in market share; a unit increase in effective recovery systems will lead to a 0.079322 increase in market share; a unit increase in promotions will lead to a 0.235632 increase in market share; a unit increase in creating customer bonds will lead to a 0.112259 increase in market share; a unit increase in building commitment will lead to a 0.112259 increase in market share; a unit increase in market intelligence will lead to a 0.381246 increase in market share; a unit increase in extraordinary customer service will lead to a 0.232361 increase in market share. On the whole, the study observed that most of the customer retention strategies at Cellmed has a positive effect on increasing the market share. The findings in detail however indicate that the most significant customer retention strategies are market intelligence and extraordinary customer service followed by monitoring customer relationships. The least significant retention strategy is customer clubs. On the other hand, loyalty programs have a negative coefficient $(-0.07)$ which means that it is a negative retention strategy. [15]; [8] in their study also pointed out that loyalty programs can provide barriers to customers switching to another supplier and that switching costs is an important antecedent of customer loyalty. While theoretical arguments favour for a positive effect of loyalty programs on market share, empirical researchers have questioned this effect [7]. 
Impact of Customer Retention Strategies on Profitability Table 5: Impact of customer retention strategies on profit

\begin{tabular}{|c|c|c|c|c|c|c|}
\hline $\begin{array}{l}\text { Independe } \\
\text { nt } \\
\text { Variables }\end{array}$ & Coef. & oIM & $\mathbf{Z}$ & $\begin{array}{l}\mathbf{P}>\mid \mathbf{z} \\
\mid\end{array}$ & $\begin{array}{l}{[95 \%} \\
\text { Conf. }\end{array}$ & $\begin{array}{l}\text { Interv } \\
\text { al] }\end{array}$ \\
\hline $\begin{array}{l}\text { a.Constan } \\
\text { t }\end{array}$ & 0.239 & $\begin{array}{l}\text { Std. } \\
\text { Err }\end{array}$ & & & & \\
\hline $\begin{array}{l}\text { M } \\
\text { customer } \\
\text { relationshi } \\
\text { ps }\end{array}$ & $\begin{array}{r}0.3 \\
68593\end{array}$ & $\begin{array}{r}0.0 \\
52297\end{array}$ & $.71^{5}$ & 0 & $\begin{array}{l}0.19609 \\
32\end{array}$ & $\begin{array}{r}0.4 \\
01093\end{array}$ \\
\hline $\begin{array}{l}\text { Loyalty } \\
\text { programs }\end{array}$ & $\begin{array}{c}0.1 \\
21581\end{array}$ & $\begin{array}{r}0.0 \\
47713\end{array}$ & $.67^{3}$ & $\begin{array}{r}0 \\
.012\end{array}$ & \begin{tabular}{l}
\multicolumn{1}{c}{-} \\
0.01393 \\
52
\end{tabular} & $\begin{array}{r}0.2 \\
73095\end{array}$ \\
\hline $\begin{array}{l}\text { Customer } \\
\text { clubs }\end{array}$ & $\begin{array}{l}- \\
.31679 \\
2\end{array}$ & $\begin{array}{c}0.0 \\
53561\end{array}$ & .01 & $\begin{array}{r}0 \\
.068\end{array}$ & \begin{tabular}{l}
\multicolumn{1}{c}{-} \\
0.20276 \\
73
\end{tabular} & $\begin{array}{l}0.3718 \\
47\end{array}$ \\
\hline $\begin{array}{l}\text { Effective } \\
\text { RS }\end{array}$ & $\begin{array}{r}0.0 \\
65291\end{array}$ & $\begin{array}{r}0.0 \\
70196\end{array}$ & $.22^{3}$ & $\begin{array}{r}0 \\
.134\end{array}$ & \begin{tabular}{l}
\multicolumn{1}{c}{-} \\
0.05225 \\
91
\end{tabular} & $\begin{array}{r}0.2 \\
22902\end{array}$ \\
\hline $\begin{array}{l}\text { Promotion } \\
\mathrm{s}\end{array}$ & $\begin{array}{r}0.5 \\
38632\end{array}$ & $\begin{array}{r}0.2 \\
35362\end{array}$ & $.16^{4}$ & $\begin{array}{r}0 \\
.235\end{array}$ & \begin{tabular}{l}
\multicolumn{1}{c}{-} \\
0.36285 \\
66
\end{tabular} & $\begin{array}{r}0.3 \\
62133\end{array}$ \\
\hline $\begin{array}{l}\text { Customer } \\
\text { bonds }\end{array}$ & $\begin{array}{r}0.2 \\
12259\end{array}$ & $\begin{array}{r}0.0 \\
51516\end{array}$ & $.18^{2}$ & $\begin{array}{r}0 \\
.029\end{array}$ & $\begin{array}{l}0.01128 \\
95\end{array}$ & $\begin{array}{r}0.1 \\
13228\end{array}$ \\
\hline $\begin{array}{l}\text { Build } \\
\text { commitme } \\
\text { nt }\end{array}$ & $\begin{array}{r}0.1 \\
32259\end{array}$ & $\begin{array}{r}0.1 \\
47664\end{array}$ & $.52^{1}$ & $\begin{array}{r}0 \\
.129\end{array}$ & \begin{tabular}{l}
\multicolumn{1}{c}{-} \\
0.06496 \\
51
\end{tabular} & $\begin{array}{r}0.4 \\
13866\end{array}$ \\
\hline $\begin{array}{l}\text { Market } \\
\text { intelligenc } \\
\mathrm{e}\end{array}$ & $\begin{array}{r}0.5 \\
33246\end{array}$ & $\begin{array}{r}0.0 \\
64104\end{array}$ & $.95^{5}$ & $\begin{array}{c}0 \\
.000\end{array}$ & $\begin{array}{l}0.25560 \\
51\end{array}$ & $\begin{array}{r}0.3 \\
06894\end{array}$ \\
\hline $\begin{array}{l}\text { Extraordin } \\
\text { ary CS }\end{array}$ & $\begin{array}{r}0.4 \\
27361\end{array}$ & $\begin{array}{r}0.3 \\
35681\end{array}$ & $.65^{3}$ & $\begin{array}{c}0 \\
.023\end{array}$ & \begin{tabular}{l}
\multicolumn{1}{c}{-} \\
0.20276 \\
73
\end{tabular} & $\begin{array}{r}0.3 \\
71847\end{array}$ \\
\hline Fit Indices & & & & & & \\
\hline chi-square & 0 & & & & & \\
\hline $\begin{array}{l}\text { degrees of } \\
\text { freedom }\end{array}$ & 0 & & & & & \\
\hline p-value & 0 & & & & & \\
\hline RMSEA & 0 & & & & & \\
\hline CFI & 1 & & & & & \\
\hline SRMR & 0 & & & & & \\
\hline TLI & 1 & & & & & \\
\hline \multicolumn{3}{|c|}{ b.Dependent variable : Profit } & & & & \\
\hline
\end{tabular}

Source: Authors' Field work (2018)

The results shown in table 5 above indicate that customer retention strategies are statistically significant in influencing on profit. The result indicates that taking all factors (monitoring customer relationships, loyalty programs, customer clubs, effective recovery systems, sales promotions, creating customer bonds, build commitment, market intelligence and extraordinary customer service) constant at zero, gross profit will be -0.239 . The findings also show that a unit increase in monitoring customer relationships will lead to a 0.368 increase in gross profit; a unit increase in loyalty programs will lead to a 0.121 increase in gross profit; a unit increase in customer clubs will lead to a -0.3168 increase in gross profit; a unit increase in effective recovery systems will lead to a 0.0652 increase in gross profit; a unit increase in promotions will lead to a 0.538 increase in gross profit; a unit increase in creating customer bonds will lead to a 0.21 increase in gross profit; a unit increase in building commitment will lead to a 0.13 increase in gross profit; a unit increase in market intelligence will lead to a 0.533 increase in gross profit; a unit increase in extraordinary customer service will lead to a 0.427 increase in gross profit. From the findings, the most significant customer retention strategy in improving profit is promotions, market intelligence and extraordinary customer service. Conversely, effective recovery systems and creating customer bonds are the least significant retention strategies in improving profit. Customer clubs and building commitment on the other hand have negative coefficients and therefore are negative strategies. [24] in his study noted that, depending on the industry type, a 5\% improvement in customer retention results in a corresponding increase in profitability to a range from $25 \%$ to $85 \%$ in terms of net present value. [13] in their study also concluded that profits in service industries increase in direct proportion to the length of a customer's relationship.

\section{Impact of Customer Retention Strategies on Sales Turnover}

The respondents were asked to rate on a five-point Likert scale the extent to which customer retention strategies influence turnover and findings are presented in Table 4.8 below. The results of the relationship between sales turnover and customer retention strategies revealed that there is a significant relationship between the dependant variable (sale turnover) and the independent variables (monitoring customer relationships, loyalty programs, promotions, extraordinary customer service, build commitment and creating customer bonds), therefore there are future economic benefits. From the study, taking all factors (independent variables) constant at zero, sales turnover will be -3.56 . The study observed that an increase in monitoring customer relationships, promotions, market intelligence, extra ordinary customer services and creating customer bonds leads to a positive increase in turnover. On the other hand, an increase in increase in loyalty programs; an increase in customer clubs, a unit increase in building commitment does not lead to an increase in sales turnover. The study details that the customer retention strategies at Cellmed are significant in increasing the turnover and revenue of the organisation. Promotions are an important tool at Cellmed for increasing sales. The findings therefore become consistent with a study by [10] where he observed that top management are widely using sales promotions as effective tools to increase their turnovers. 
Table 6: Impact of Customer Retention Strategies on Revenue/Turnover

\begin{tabular}{|c|c|c|c|c|c|c|}
\hline $\begin{array}{l}\text { Independe } \\
\text { nt } \\
\text { Variables }\end{array}$ & Coef. & oIM & $\mathbf{Z}$ & $\begin{array}{l}\mathbf{P}>\mid \\
\mathbf{z} \mid\end{array}$ & $\begin{array}{l}{[95 \%} \\
\text { Conf. }\end{array}$ & $\begin{array}{l}\text { Interval } \\
]\end{array}$ \\
\hline $\begin{array}{l}\text { a.Constan } \\
\mathrm{t}\end{array}$ & $\begin{array}{r}- \\
3.56 \\
\end{array}$ & $\begin{array}{c}\text { Std } \\
\text {. Err }\end{array}$ & & & & \\
\hline $\begin{array}{l}\text { M } \\
\text { customer } \\
\text { relationshi } \\
\text { ps }\end{array}$ & $\begin{array}{r}0.1 \\
81593\end{array}$ & $\begin{array}{r}0.0 \\
52297\end{array}$ & $.31^{4}$ & 0 & $\begin{array}{l}0.16109 \\
32\end{array}$ & $\begin{array}{c}0.34 \\
1093\end{array}$ \\
\hline $\begin{array}{l}\text { Loyalty } \\
\text { programs }\end{array}$ & $\begin{array}{l}{ }^{-}- \\
0.1158 \\
1\end{array}$ & $\begin{array}{r}0.0 \\
47713\end{array}$ & $.67^{3}$ & $\begin{array}{r}0 \\
.012\end{array}$ & $\begin{array}{l}- \\
0.01493 \\
52\end{array}$ & $\begin{array}{c}0.18 \\
3095\end{array}$ \\
\hline $\begin{array}{l}\text { Customer } \\
\text { clubs }\end{array}$ & $\begin{array}{l}0.4539 \\
2 \\
\end{array}$ & $\begin{array}{c}0.0 \\
53561\end{array}$ & $.01^{1}$ & $\begin{array}{r}0 \\
.068\end{array}$ & $\begin{array}{l}{ }^{-}- \\
0.20276 \\
73\end{array}$ & $\begin{array}{l}0.27318 \\
47 \\
\end{array}$ \\
\hline $\begin{array}{l}\text { Effective } \\
\text { RS }\end{array}$ & $\begin{array}{r}0.2 \\
06322\end{array}$ & $\begin{array}{r}0.0 \\
70196\end{array}$ & $.22^{3}$ & $\begin{array}{r}0 \\
.134\end{array}$ & $\begin{array}{l}- \\
0.04225 \\
91\end{array}$ & $\begin{array}{c}0.22 \\
2902\end{array}$ \\
\hline $\begin{array}{l}\text { Promotion } \\
\text { s }\end{array}$ & $\begin{array}{r}0.1 \\
74632\end{array}$ & $\begin{array}{r}0.0 \\
36851\end{array}$ & $.33^{2}$ & $\begin{array}{r}0 \\
.318\end{array}$ & \begin{tabular}{l}
\multicolumn{1}{c}{-} \\
0.23263 \\
11
\end{tabular} & $\begin{array}{c}0.31 \\
1526\end{array}$ \\
\hline $\begin{array}{l}\text { customer } \\
\text { bonds }\end{array}$ & $\begin{array}{r}0.3 \\
02259\end{array}$ & $\begin{array}{r}0.0 \\
51516\end{array}$ & $.88^{2}$ & $\begin{array}{r}0 \\
.029\end{array}$ & $\begin{array}{l}0.01228 \\
95 \\
\end{array}$ & $\begin{array}{c}0.26 \\
3228\end{array}$ \\
\hline $\begin{array}{l}\text { Build } \\
\text { commitme } \\
\text { nt }\end{array}$ & $\begin{array}{l}- \\
.25815 \\
9 \\
\end{array}$ & $\begin{array}{r}0.1 \\
47664\end{array}$ & $.52^{1}$ & $\begin{array}{r}0 \\
.129\end{array}$ & \begin{tabular}{l}
\multicolumn{1}{c}{-} \\
0.07496 \\
51
\end{tabular} & $\begin{array}{c}0.41 \\
3866\end{array}$ \\
\hline $\begin{array}{l}\text { Market } \\
\text { intelligenc } \\
\mathrm{e}\end{array}$ & $\begin{array}{r}0.2 \\
61246\end{array}$ & $\begin{array}{r}0.0 \\
64104\end{array}$ & $.95^{5}$ & $\begin{array}{r}0 \\
.000\end{array}$ & $\begin{array}{l}0.25560 \\
51 \\
\end{array}$ & $\begin{array}{l}0.40 \\
6894\end{array}$ \\
\hline $\begin{array}{l}\text { Extraordin } \\
\text { ary CS }\end{array}$ & $\begin{array}{r}0.3 \\
02361\end{array}$ & $\begin{array}{r}0.3 \\
35681\end{array}$ & $.65^{3}$ & $\begin{array}{r}0 \\
.023\end{array}$ & $\begin{array}{l}- \\
0.21276 \\
73\end{array}$ & $\begin{array}{c}0.27 \\
1847\end{array}$ \\
\hline \multicolumn{7}{|l|}{ Fit Indices } \\
\hline chi-square & 0 & & & & & \\
\hline $\begin{array}{l}\text { degrees of } \\
\text { freedom }\end{array}$ & 0 & & & & & \\
\hline p-value & 0 & & & & & \\
\hline RMSEA & 0 & & & & & \\
\hline CFI & 1 & & & & & \\
\hline SRMR & 0 & & & & & \\
\hline TLI & 1 & & & & & \\
\hline b.Depen & & & & & & \\
\hline
\end{tabular}

\section{Source: Authors' Field work (2018)}

\section{Ways of enhancing customer retention}

Customers have different perceptions about the organisation and the perception they hold is vital in them choosing on which organisation to buy products and services from. It is therefore important for the various firms in the medical sector to continually develop, enhance and improve on customer retention strategies. Making available a wide range of products as well as developing innovative and customised products is crucial in improving customer retention. Moreover, reducing the waiting period for claims is also vital in improving customer retention. This means Cellmed Health can reduce the period of waiting before one can start claiming after the initial contract with the firm. Another very important dimension of retaining customer is the price of the services. Pricing is a very important determinant in customer retention. If prices are not competitive enough Cellmed can face problems in self- marketing and selling its products. [3] in their study observed that improved level of service quality is related to higher revenues, higher customer retention and expanded market share. Thus, companies must understand that customer will be loyal only if the greater value is provided by them as compared to competitors. While analysing this dimension in the study various parameters are taken like twenty-four hours $(24 * 7)$ toll free services, transaction alerts through SMS and E-mail, regular policy statements, easy claim settlement policies and procedures, satisfaction from services and willingness to renew insurance policies. These services play critical role in retaining the customer. Similarly, cashless facility is another important feature of service where customer can get medical treatment facility without bothering for cash payments at the time of medical emergency, also considering the cash crisis in Zimbabwe at the moment. Easy accessibility of services, availability of branch offices and sufficient number of networks hospitals are also important in improving customer retention. For health insurance, customer values services to be easily available in form of company offices for easy access, hence the services with the help of infrastructural support are required by services sectors.

\section{SUMMARY, CONCLUSIONS AND RECOMMENDATIONS}

The study concludes that monitoring customer relationships, market intelligence and promotions constitutes the most widely used retention strategies. Strategies which have been adopted to a moderate extent include extraordinary services, creating bonds and building commitment. Strategies adopted to a small extent included customer clubs and effective recovery systems creating bonds binding the customer to the firm was the least adopted customer retention strategy. The study conclusion was that there exists a significant relationship between customer retention strategies at Cellmed Health and market share. The study revealed that there exists a significant relationship between customer retention strategies and profit and the strategies employed by Cellmed are significant in improving profitability. The results of the impact of customer retention strategies at Cellmed Health on turnover revealed that there is a significant relationship between customer retention and sales turnover. The study conclusion was that Insurance industry was the strategies employed by Cellmed are significant in improving profitability. The study concludes also that the customer retention strategies are effective in giving the company a competitive edge in the medical industry. Improving customer retention strategies at Cellmed Health requires a focus on continuous customer surveys, process management, updating of customer files, early identification of dissatisfied customers, tracking of dissatisfied customers. In terms of responsiveness there is need to address all customer queries and complaints, fulfilling all claim commitments, quick response to messages that come through the various platforms. In terms of services, improve on know your customer initiatives, easy claim settlement policies and procedures.in terms of tangibility there is need for easy accessibility of services, availability of branch offices and sufficient number of network hospitals. In terms of price there is need to be 
transparent in charges and setting up competitive premiums and other charges. Enhancing customer retention should embrace decisions about product, price, services, responsiveness, tangibility and reliability of the brand name. Based on the study findings and conclusions, the researchers recommends that Cellmed Health should strengthen its customer bonds. Improving customer bonds enables the firm and its customers to both commit resources to the relationship built on high levels of trust and commitment. Having a relationship based on trust and commitment will improve and increase customer retention, market share and brings a growth in sales volumes. Moreover, in order to increase customer retention rates, Cellmed Health should provide extraordinary customer service. This means it must go above and beyond the customers' expectations. In that regard it can achieve that by having a dedicated outstanding team to ensure customer satisfaction that provide instant and or immediate response to customer complaints and queries, deliver consistently on-time on all services and fulfilling all the promises to its customers in terms of settling claims. From the study findings, these methods will result to significant increases in market share, turnover as well as gross profits to the firm. The researchers also recommends that Cellmed Health should allocate budgets to building customer clubs. In a study by [23] it was noted that increasing the customer retention rate requires creating close contacts around the client throughout the customer relationship life cycle. The study observed that customer clubs was among the least adopted customer retention strategy at Cellmed Health. Therefore, the researcher recommends that in order for Cellmed Health to improve the customer retention rate it must expand its strategies and incorporate customer clubs in order to gain more understanding of its customers. Moreover, Cellmed Health must continue to adopt customer retention strategies and ensure they are effective. The costs of customer retention activities are less than the costs of acquiring new customers and financial implications of attracting new customers may be five times as costly as keeping existing customers. The researcher further recommends that firms need to analyse their customers before coming up with strategies of retaining them. Cellmed Health need to come up with ways of rewarding the marketing and sales staff for retaining customers.

\section{REFERENCES}

[1] Association of Healthcare Medical Funders Zimbabwe Report (2018).

[2] Babbie, E. \& Mouton, J. (2002). The practice of Social Research. Cape Town: OUP

[3] Bolton, K and Mathew D. Bramlett (2000), "Implications of Loyalty Program Membership and Service Experiences for Customer Retention and Value," Journal of the Academy of Marketing Science, 28 (winter), 95-108.

[4] Bolton, R.N. (1998) "A Dynamic Model of the Duration of the Customer's Relationship with a Continuous Service Provider: the role of Satisfaction", Marketing Science, Vol. 17 No. 1, pp. $45-65$.

[5] Buttle, F. (2008). Customer Relationship Management Concepts and Technologies Second edition, Butterworth, USA. 54.

[6] Dick, A. S. and Kunal. B. (1994), "Customer Loyalty: Toward an Integrated Conceptual Framework," Journal of the Academy of Marketing Science, 22 (Spring), 99-113.
[7] Dowling, G. and Uncles, M. (1997). Do customer loyalty programs really work? Sloan Management Review, Vol. 38(4), Summer, pp. 71-82.

[8] Klemperer. P. (1995), “Competition When Consumers Have Switching Costs: An Overview with Applications to Industrial Organization, Macro Economics, and International Trade," The Review of Economic Studies, 62 (4), 515-39.

[9] Kotler, P and Keller K.L. (2006) Marketing Management, Pearson Prentice Hall 12th Edition.

[10] Kotler, P. (2003). Marketing Management. 11th Ed., Pearson International, London. Lasting Value. Massachusetts, MA: Harvard Business School Press.

[11] Kotler, P. and K.L. Keller, (2008). Marketing Management, 3th Ed., Prentice Hall, New Jersey.

[12] Mugenda, O. M., and Mugenda, A. G. (2003). Research methods: Quantitative and qualitative approaches. Nairobi, Kenya: Act Press.

[13] O’Brien, L. and Jones, C. (1995) Do rewards really create loyalty? Harvard Business Review, Vol. 73(3), May, pp. 75-82.

[14] Omwebu, M. B (2015). Customer Retention Strategies Used By Barclays Bank Of Kenya Limited In Its International Operation. University of Nairobi.

[15] Payne, A. F and Frow, P.E. (1999). Developing a segmented service strategy: improving measurement in relationship marketing. Journal of Marketing Management 15, 797-818.

[16] Reichheld, F. F (1996). The Loyalty Effect: The Hidden Force behind Growth, Profits and Lasting Value. Massachusetts, MA: Harvard Business School Press.

[17] Reichheld, F. F. (1993) Loyalty-based management. Harvard Business Review, March, pp. 63-73.

[18] Reichheld, F. F. (1996). Learning from Customer Defection. Harvard. Business Review: 56-69.

[19] Reichheld, F. F., \& Sasser, W .E. (1990). Zero Defection: Quality Comes to Services. Harvard Business Review: 105-111.

[20] Reichheld, F.F (1996). The Loyalty Effect: The Hidden Force behind Growth, Profits and Lasting Value. Massachusetts, MA: Harvard Business School Press.

[21] Reichheld, F.F. (1996). Learning from Customer Defection. Harvard. Business Review: 56-69.

[22] Reichheld, F.F., \& Sasser, W .E. (1990). Zero Defection: Quality Comes to Services. Harvard Business Review: 105-111.

[23] Stauss, B., Decker A., \& Hoffman. F. (2001). Retention effects of a customer club. International Journal of Service Industry management, 11(5), pp. 470-490.

[24] Waithaka, L. W. (2014). Influence of Customer Retention Strategies on Performance of Insurance Companies in Nairobi, Kenya.

[25] Zeithaml, V.A. and Bitner, M.J. (1996). Services Marketing. Singapore: McGraw-Hill.

[26] Zeithaml, V.A., A. Parasuraman, and A. Malhotra (2000). "Service Quality Delivery through Web Sites: A Critical Review of Extant Knowledge." Journal of the Academy of Marketing Science. Vol.30 No.4, 362-75. 
